\title{
Automatic Milking Systems, Farm Size, and Milk Production
}

\author{
C. A. Rotz, C. U. Coiner, and K. J. Soder \\ USDA/Agricultural Research Service, \\ Pasture Systems and Watershed Management Research Unit, \\ Building 3702, Curtin Road, University Park, PA 16802
}

\begin{abstract}
Automatic milking systems (AMS) offer relief from the demanding routine of milking. Although many AMS are in use in Europe and a few are used in the United States, the potential benefit for American farms is uncertain. A farm-simulation model was used to determine the long-term, whole-farm effect of implementing AMS on farm sizes of 30 to 270 cows. Highest farm net return to management and unpaid factors was when AMS were used at maximal milking capacity. Adding stalls to increase milking frequency and possibly increase production generally did not improve net return. Compared with new traditional milking systems, the greatest potential economic benefit was a single-stall AMS on a farm size of 60 cows at a moderate milk production level $(8600 \mathrm{~kg} / \mathrm{cow})$. On other farm sizes using single-stall type robotic units, losses in annual net return of $\$ 0$ to $\$ 300 /$ cow were projected, with the greatest losses on larger farms and at high milk production $(10,900 \mathrm{~kg} / \mathrm{cow})$. Systems with one robot serving multiple stalls provided a greater net return than single-stall systems, and this net return was competitive with traditional parlors for 50- to 130-cow farm sizes. The potential benefit of AMS was improved by $\$ 100 /$ cow per year if the AMS increased production an additional 5\%. A 20\% reduction in initial equipment cost or doubling milking labor cost also improved annual net return of an AMS by up to $\$ 100 / \mathrm{cow}$. Annual net return was reduced by $\$ 110 /$ cow, though, if the economic life of the AMS was reduced by $3 \mathrm{yr}$ for a more rapid depreciation than that normally used with traditional milking systems. Thus, under current assumptions, the economic return for an AMS was similar to that of new parlor systems on smaller farms when the milking capacity of the AMS was well matched to herd size and milk production level.
\end{abstract}

(Key words: robotic milking, farm simulation, economics, DAFOSYM)

Received August 8, 2002

Accepted May 29, 2003

Corresponding author: C. A. Rotz; e-mail: alrotz@ars.usda.gov.

\begin{abstract}
Abbreviation key: AMS = automatic milking system (s), DAFOSYM = Dairy Forage System Model, 2× = twice daily milking frequency, $\mathbf{3} \times=$ three times a day milking frequency, $\mathbf{2 . 5} \times=$ an average 2.5 times a day milking frequency.
\end{abstract}

\section{INTRODUCTION}

On smaller dairy farms, milking is a time-consuming and demanding chore that is often done by the farm family. When hired labor is used, it is often difficult to maintain due to the competition from other employment opportunities with greater pay and benefits. Automatic milking systems (AMS) offer a method for relieving the farmer from this labor-intensive routine (Reinemann and Smith, 2001). Although future improvements will be made, this technology is now well developed for use on commercial farms. In Europe, at least 1000 farms are using automatic milking, and several units are operating on Canadian farms (de Koning et al., 2002). This technology is used experimentally on a few farms in the United States awaiting approval by government regulatory agencies.

Automatic milking systems offer two major advantages. The first is a reduction in labor for milking. When automatic milking replaces hired labor, an annual savings of up to $\$ 200 /$ cow may be obtained (Dijkhuizen et al., 1997). When the farm owner's labor is replaced, realized savings are less tangible but likely more valuable. Use of automatic milking can free time for farm management, family, and recreational activities. A second potential benefit is increased milk production. Automatic milking systems normally allow cows to be milked up to three times each day $(\mathbf{3} \times)$, which can increase milk production from 3 to $11 \%$ over the common twice a day milking $(\mathbf{2} \times)$ strategy (de Koning et al., 2002; Baines, 2002).

Automatic milking systems also have disadvantages. A primary disadvantage is that they require a large initial investment. For a given herd, the initial equipment cost is often two to three times that required for a traditional milking parlor. Another potential disadvantage is in milk quality (Klungel et al., 2000). With an increase in production through more frequent milking, the milk fat concentration is slightly lower than 
that obtained with traditional twice daily milking (Klungel et al., 2000; Shoshani and Chaffer, 2002). Furthermore, more feed must be consumed to meet the greater production, thus raising feed costs. Bacteria counts in milk can be higher due to a greater opportunity for microorganisms to enter and multiply during the milking process. However, with improvements in animal management, udder washing, and milk precooling, bacteria levels similar to traditional parlor systems can be attained (Baines, 2002; Rasmussen et al., 2002).

Automatic milking systems appear most feasible for smaller dairy farms commonly found in the northeastern and upper Midwestern states (Reinemann and Smith, 2001). Many of these farms are expanding to combat low milk prices and decreasing farm profit. With this expansion, either more labor or more efficient use of labor is required. In addition, aging facilities must be improved or expanded. Facing these challenges, AMS provides an alternative to traditional milking parlors and hired labor.

A deterrent to the adoption of AMS is a lack of knowledge on the whole-farm impacts, particularly economic impacts, of implementing this technology. The adoption of AMS affects the investment in facilities and equipment, milk production, feed use, energy use, and labor requirements. A whole-farm simulation model such as the Dairy Forage System Model (DAFOSYM) provides a useful tool for integrating these effects and evaluating the impact of these changes before they are implemented on a real farm. This model was previously used to evaluate the feasibility of using an AMS on an actual farm in southern Pennsylvania (Rotz et al., 2001). The use of high-producing animals and a proper match of the capacity of the milking system to the number of animals were reported as important factors affecting the potential economic benefit of this new technology.

Previous studies have evaluated the economic feasibility of AMS compared with traditional milking systems. Breakeven analyses show that the investment and operating costs over the life of an AMS can be comparable to those of traditional milking systems, but this comparison is dependent on the assumptions of the analysis (Dijkhuizen et al., 1997; Hyde and Engel, 2002). Important considerations include milking labor costs, herd milk production, and the life of the equipment. A breakeven analysis provides a good tool for assessing the economic feasibility of alternative milking systems, but this approach simplifies the interactions with other parts of the farm.

This study was developed to evaluate the interaction of AMS use with farm size and animal production level. The objective was to compare long-term farm profitability using new traditional and automatic milking systems on farm sizes of 30 to 270 cows at moderate and high production levels. A whole-farm approach was used that included the effect on milk production, milk quality, feed use, and any resulting environmental impacts from manure nutrient cycling.

\section{MATERIALS AND METHODS}

Production systems were compared using the dairy option of the integrated farm system model. This wholefarm simulation model is an expanded version of DAFOSYM that includes beef and crop farming options. Crop production, feed use, and the return of manure nutrients to the land are simulated over many weather years (Rotz et al., 1999b; Rotz and Coiner, 2002). Growth and development of alfalfa, grass, corn, soybean, and small grain crops are predicted from daily soil and weather conditions. Tillage, planting, harvest, and storage operations are simulated to predict resource use, timeliness of operations, crop losses, and nutritive changes in feeds. Feed allocation and animal response are related to the nutritive value of available feeds and the nutrient requirements of the animal groups making up the dairy herd (Rotz et al., 1999a). Nutrient flows through the farm predict potential nutrient accumulation and loss to the environment (Rotz et al., 1999b).

Simulated performance is used to determine production costs, income, and farm net return for each weather year. A whole-farm budget is used in which investments in equipment and structures are amortized over their economic life considering a real rate of return. Annual resource requirements and produce predicted by the model are used to determine annual operating expenditures and incomes (Rotz and Coiner, 2002). The annual net return to management and unpaid factors is determined as the sum of the incomes from the sale of milk, animals, and excess feed minus operating costs for animal maintenance, milking and feeding, feed production, and manure handling. By simulating and comparing production options, the long-term economic and environmental effects of production changes are measured.

\section{Farm Description}

The impact of milking system type was evaluated for confinement dairy farms ranging in size from 30 to 270 (lactating and dry) Holstein cows in increments of 10 cows. Farms were simulated over 25 yr (1974 through 1998) of State College, Pennsylvania, weather. Farmland area was set to provide all of the forage and some of the grain required to feed the herd during most weather years. With a loam soil of medium depth, the required cropland was 0.81 ha per cow divided equally between alfalfa and corn production. Both crops were primarily harvested as silage, with remaining corn harvested as dry grain. 
Table 1. Economic parameters and prices assumed for various system inputs and outputs for the analysis of the representative dairy farms.

\begin{tabular}{|c|c|c|c|}
\hline Parameter & Value $(\$)^{1}$ & Parameter & Value $(\$)$ \\
\hline \multicolumn{2}{|l|}{ Initial cost of animal facilities } & \multicolumn{2}{|l|}{ Buying price of feeds } \\
\hline Free-stall barn & $\$ 1000 /$ cow & Corn & $\$ 125 / \mathrm{t} \mathrm{DM}$ \\
\hline Heifer housing & $\$ 620 /$ heifer & Soybean meal & $\$ 310 \mathrm{t} \mathrm{DM}$ \\
\hline Commodity shed & $\$ 70 /$ cow & Protein mix & $\$ 330 / \mathrm{t} \mathrm{DM}$ \\
\hline \multicolumn{2}{|l|}{ Custom costs } & Mineral vitamin mix & $\$ 350 / \mathrm{t} \mathrm{DM}$ \\
\hline Tillage and planting & $\$ 120 / \mathrm{ha}$ & Vegetable oil & $\$ 440 / \mathrm{t} \mathrm{DM}$ \\
\hline Mowing & $\$ 28 / \mathrm{ha}$ & Labor wage rate & $\$ 9.00 / \mathrm{h}$ \\
\hline Raking & $\$ 16 / \mathrm{ha}$ & Mailbox milk price & $\$ 0.29 / \mathrm{kg}$ \\
\hline Silage harvest \& silo fill & $\$ 7.20 / \mathrm{t}$ & Total of livestock expenses & $\$ 238 /$ cow/yr \\
\hline Grain harvest & $\$ 61.80 / \mathrm{ha}$ & Bovine somatotropin & $\$ 120 /$ cow/yr \\
\hline Manure spreading & $\$ 70 / \mathrm{h}$ & Economic life & \\
\hline \multicolumn{2}{|l|}{ Annual cost of seed and chemicals } & Structures & $20 \mathrm{yr}$ \\
\hline New alfalfa & $\$ 200 / \mathrm{ha}$ & Equipment & $10 \mathrm{yr}$ \\
\hline Established alfalfa & $\$ 15 / \mathrm{ha}$ & Salvage value & \\
\hline Corn following corn & $\$ 165 /$ ha & Structures & $0 \%$ \\
\hline \multirow[t]{3}{*}{ Corn following other crop } & $\$ 135 / \mathrm{ha}$ & Equipment & $30 \%$ \\
\hline & & Property tax rate & $2.3 \%$ \\
\hline & & Real interest rate & $6.0 \% / \mathrm{yr}$ \\
\hline
\end{tabular}

${ }^{1}$ Prices represent long-term averages in current value, which are not necessarily current market prices.

All field operations were simulated through time, considering the interactions with other farm operations. For this analysis though, the cost of performing the operations was set using custom or contract charges for this region (Table 1; Shimmin and Stout, 2002). This assumption allowed a smoother transition in feed production costs across farm sizes. Annual custom costs were similar to the annual costs predicted by the model for owning and operating equipment. Equipment owned by the farmer included a mobile feed mixer, a tractor to operate the mixer, and loaders for feeding and manure scraping.

Facilities on the farm included a machine shed and shop, feed storage, and animal housing. The initial cost of the machine shed was set at $\$ 1000 \times$ the number of cows on the farm up to a maximum of $\$ 100,000$. Silage was stored in bunker silos. Equally sized silos were used for corn and alfalfa silage, with a total capacity of about 6.1 tonne DM/cow. Silo costs dropped from $\$ 200$ to $\$ 100 /$ tonne DM of storage capacity with increasing silo size. Animals were housed in free-stall barns sized according to the number of animals (Table 1). For farms with 100 or more cows, purchased feeds were stored in a commodity shed, but on smaller farms a low-cost storage for premix was used (Table 1).

The dairy herd included heifers raised on the farm. The culling rate for all herd sizes was set at $35 \%$, which established the number of replacement heifers required. A few additional heifers were raised to allow for culling decisions and mortality. All animals were fed TMR. Manure was stored in a lined pit with a 6mo storage capacity. All manure was utilized on the crops grown, with $80 \%$ applied to corn land. The manure was surface applied and incorporated by tillage soon after application.

All prices were held constant across simulated years and set to reflect long-term average values in current dollars (Table 1). Constant prices assured that economic differences among years were solely due to weather effects on farm performance. Equipment and facility investments were amortized using a real interest or discount rate (approximately nominal rate minus inflation) of $6 \%$ per year. Property tax was charged at $2.3 \%$ of the estimated assessed value of property. Property included all buildings on each farm but not the milking equipment. The wage rate for all labor required on the farm was set at $\$ 9 / \mathrm{h}$. Operating costs included annual livestock expenses of $\$ 238 / \mathrm{cow}$, which consisted of veterinary, breeding, animal supplies, utilities, animal registration, and similar annual costs. Tax incentives or other government contributions were not considered in the economic analysis.

\section{Primary Analysis}

Simulations were used to compare traditional and automatic milking systems on each farm size at two milk production levels. Milk production with $2 \times$ milking was set at $8600 \mathrm{~kg} / \mathrm{cow}$ (moderate) or $10,900 \mathrm{~kg} / \mathrm{cow}$ (high). To maintain the moderate production level, animals were fed farm-grown forage, corn grain, soybean meal, and a protein mix with low rumen degradability. For the high production level, dietary changes included vegetable oil to increase the energy content of the diet, and the animals were treated with bST at an annual cost of $\$ 120 /$ cow. Although bST use was assumed, this 
Table 2. Economic parameters assumed for milking equipment and structures.

\begin{tabular}{lllllll}
\hline & \multicolumn{2}{c}{ Traditional parlor } & & \multicolumn{2}{c}{ Automatic milking } \\
\cline { 2 - 3 } \cline { 5 - 6 } & Structure & Equipment & & Structure & Equipment \\
\hline Purchase and installation price (\$1000/stall) & 6.0 to $7.8^{1}$ & 9.0 to $10^{2}$ & & 17 & 175 to $60^{3}$ \\
Economic life (yr) & 20 & 10 & & 20 & 10 \\
Salvage value (\% of purchase price) & 0 & 10 & & 0 & 10 \\
Insurance (\% of purchase price) & 0.5 & 0.5 & & 0.5 & 0.5 \\
Repair and maintenance (\% of purchase price) & 0.5 & 3.0 & & 0.5 & $4.2^{4}$ \\
Milking and handling labor (min/cow per day) & & 3 to $4^{6}$ & & \\
\hline
\end{tabular}

\footnotetext{
${ }^{1}$ Structure costs decreased from $\$ 7800 /$ stall for a double-six parlor to $\$ 6050 /$ stall for a double-ten parlor with a cost of $\$ 2400 /$ stall for a stanchion barn.

${ }^{2}$ Equipment costs decreased from $\$ 10,000 /$ stall for a double-six parlor to $\$ 9000 /$ stall for a double-ten parlor with a cost of $\$ 1200 /$ stall for pipeline milking. Initial parlor cost was increased $\$ 5000 /$ stall to represent a high cost parlor.

${ }^{3}$ Equipment costs decreased from $\$ 175,000$ for the first stall to $\$ 158,000$ for additional single-stall units or $\$ 60,000$ for additional stalls in a multiple-stall AMS.

${ }^{4} \mathrm{An}$ annual repair and maintenance cost for the automatic system of $\$ 700$ plus $4.2 \%$ of the purchase price included a long-term service contract plus $2 \%$ per year for additional repairs.

${ }^{5}$ Milking and handling labor included the milking operation plus time spent with animals for observation, reproduction, and health reasons.

${ }^{6}$ Daily labor varied from $3 \mathrm{~min} / \mathrm{cow}$ for the 270 -cow farm to $4 \mathrm{~min} / \mathrm{cow}$ for 60 cows with 5 to $6 \mathrm{~min} / \mathrm{cow}$ in a stanchion barn. This requirement was increased $40 \%$ for $3 \times$ milking.
}

production strategy represents any management change or genetic improvement to allow this higher production. Use of bST may be more cumbersome with an AMS, because cows are not all constrained at the same time to allow easy application of the treatment.

A milking frequency of $3 \times$ was also considered. With $3 \times$ milking in a parlor, milk production was increased by $12 \%$ over $2 \times$ (Campos et al., 1994; Speicher et al., 1994; Armstrong, 1997), and milk fat and protein contents were decreased by 0.14 and 0.06 percentage units, respectively (Speicher et al., 1994). To reflect this decrease in milk solids content, the average milk price of $\$ 0.29 / \mathrm{kg}$ was reduced $2 \%$ to a price of $\$ 0.284 / \mathrm{kg}$.

Traditional milking systems were selected of an appropriate type and size for the herd. For herds of 50 cows and under, a stall barn and pipeline system was assumed. For farms of 60 to 150 cows, parlors were sized to allow each milking to be completed within $2 \mathrm{~h}$. This time constraint was relaxed on larger farms, where hired labor was more likely to be used for milking. Parlor sizes were a double six for 60 to 100 cows, a double eight for 110 to 190 cows, and a double 10 for 200 to 270 cows (Knoblauch and Galton, 1992). The initial cost, efficiency, and labor requirement were first set to reflect a moderate cost parlor (Table 2). Automatic detachers were used, but milk recording and other monitoring equipment were not included. A higher cost parlor was then considered that included production monitoring similar to that obtained with an AMS. To represent this technology, the initial cost of the parlor equipment was increased by $\$ 5000 /$ stall. Labor requirements, which included time spent with animals for re- production and health purposes, varied with herd size and the type of milking equipment used (Table 2). Parlor structures were sized and priced to include milking, milk storage, equipment, office, and animal holding areas (Table 2).

Each farm size was then simulated using both singlestall and multiple-stall AMS. In single-stall systems, each milking stall has a robot to perform the milking functions. In multiple-stall systems, a single robot serves up to four milking stalls. The robot moves on a track to attach individual milking units in each stall. Single-stall units are more expensive when more than one stall is required, but they provide a greater milking capacity. With a robot at each stall, the robot is always available for attaching the milking unit when the cow enters. In a multiple-stall AMS, a cow may wait in a milking stall while the robot is servicing another stall, thus reducing the milking capacity per stall. Because the robot is shared across multiple stalls though, the initial cost per stall is less.

The number of AMS stalls was set to meet the required capacity at each farm size. Capacity of a singlestall AMS was the available time divided by the milking time per animal. Available time was set at $20 \mathrm{~h}$ per day to allow $4 \mathrm{~h}$ for cleaning, maintenance, and other down periods. The units were assumed to be occupied $80 \%$ of this 20 -h period (Ipema, 1997) providing $16 \mathrm{~h} /$ $\mathrm{d}$ of actual operating time. Time required to milk each animal was the milking time (daily production divided by milk removal rate) plus a preparation time of 2.0 min/cow per milking (Ipema, 1997; de Koning and Ouweltjes, 2001). Milk removal rate increased with the 
amount of milk obtained per milking from a low of 1.8 $\mathrm{kg} / \mathrm{min}$ at $9 \mathrm{~kg} / \mathrm{milking}$ to $3.2 \mathrm{~kg} / \mathrm{min}$ at $25 \mathrm{~kg} / \mathrm{milking}$ (Mein and Reid, 1996; de Koning and Ouweltjes, 2001).

The capacity of a single-stall AMS was determined for milking frequencies from 3.0 to $2.5 \times$ per day. Unit capacities for $3 \times$ milking at moderate and high production levels were 52 and 48 cows, respectively. This capacity represented the whole herd, which included approximately $15 \%$ dry cows at any point in time. As farm size increased, the throughput capacity of an AMS became limiting. When this occurred, the milking frequency was allowed to decrease to a herd average of 2.5 milkings per day $(\mathbf{2 . 5} \times)$. This gave maximum herd sizes of 60 and 55 cows per milking unit at the moderate and high production levels, respectively. After this limit was reached, another milking unit was added that provided a $3 \times$ milking frequency at the next step in farm size.

Milking capacity of a multiple-stall AMS is more difficult to assess. Milk removal time is less important, and the idle time waiting on the robot becomes a major consideration. Cleaning and preparation time are normally done in a separate stall to allow the robot to spend more time attaching milking units. Capacities of $60,100,130$, and 150 cows were assumed for units serving $1,2,3$, or 4 stalls, respectively, at the moderate milk production level (Sonck and Donkers, 1995; de Koning et al., 2002). At the higher production level, capacities were reduced $3 \%$.

Milk production attained is an important consideration in the analysis of an AMS. Although available information is inconsistent, there is good support that production will increase with automatic milking due to an increased milking frequency. However, this increase will not be as large as that attained by increasing the milking frequency in a traditional parlor due to more irregular periods between milking events. Reported production increases vary from 0 to $11 \%$ (de Koning et al., 2002; Baines, 2002; Shoshani and Chaffer, 2002; Wirtz et al., 2002). Considering this range, we assumed a maximum herd-average increase of $5 \%$. Thus, when the milking system capacity allowed a $3 \times$ or greater milking frequency, herd milk production was set $5 \%$ greater than that for $2 \times$ milking in a traditional parlor. This increase was assumed to decrease in proportion to the milking frequency with no increase at $2.5 \times$, i.e., there was a 1 percentage unit production increase for each 0.1-incremental increase in the average milking frequency above $2.5 \times$. For example, at the moderate production level on the 120-cow farm either two or three single-stall units could be used. Two units only marginally met the capacity required for this herd, so milking frequency was limited to $2.5 \times$, and milk production was equal to that of a $2 \times$ frequency in a parlor. With three units, there was excess capacity allowing at least three milkings per day and a $5 \%$ increase in production.

Use of automatic milking has consistently shown a decrease in milk fat concentration of about 0.2 percentage units (Wirtz et al., 2002; Shoshani and Chaffer, 2002; Wangler et al., 2002). In our analysis, this was reflected by a $2 \%$ decrease in mailbox milk price, when a 5\% increase in milk production was maintained. This difference in milk price was decreased to zero as the increase in milk production attained with automatic milking decreased to zero.

Automatic milking may also increase electricity use on dairy farms. Limited available information indicated that the total electrical requirement for milking and cleaning with an AMS was normally between 400 and $600 \mathrm{kwh} / \mathrm{cow}$ per year (Rasmussen and Rasmussen, 2002). A comparison to values of 250 to $400 \mathrm{kwh} / \mathrm{cow}$ per year reported for traditional parlors (Brooks, 1989; McFate, 1989) implied some increase. We assumed that when a $3 \times$ milking frequency was maintained with a single-stall AMS, electrical use increased by $190 \mathrm{kwh} /$ cow per year at an annual cost of $\$ 15 /$ cow. With a $2.5 \times$ milking frequency, this added cost was reduced to $\$ 10 /$ cow. To reflect greater electrical use in a multiple-stall AMS (Artmann and Bohlsen, 2001) electrical cost was increased by $\$ 20 /$ cow for these systems.

The initial cost and other economic parameters for the AMS units are given in Table 2. Structure cost with an AMS represents a new facility for the milking units or the renovation of an existing facility.

\section{Sensitivity Analysis}

A number of assumptions were made to support this analysis that affect the difference between automatic and traditional milking systems. These included the increase in milk production received with automatic milking, the capacity of the AMS, the initial cost, economic life, and repair and maintenance cost of the AMS equipment, labor and electrical requirements, the value of labor, and milk price. The sensitivity of the analysis to each assumption was evaluated by independently changing the appropriate parameters to determine the resulting change in net return relative to the traditional system. These effects sometimes varied across farm sizes; however, only the 120-cow farm was reported with comments regarding the effects on other farms. The AMS in these analyses was the single-stall type.

Although increased milk production appears probable with the adoption of an AMS, this increase is not consistently reported (de Koning et al., 2002; Baines, 2002; Shoshani and Chaffer, 2002; Wirtz et al., 2002). To determine this effect, automatic systems were analyzed considering 0 and $10 \%$ increases in production 
relative to a $2 \times$ frequency with traditional systems. No increase in production represents a very conservative assessment in which the only benefit of AMS is labor saving. A $10 \%$ increase is representative of the largest reported increases in production. This was modeled as a $10 \%$ increase when the capacity allowed a $3 \times$ milking frequency and a $5 \%$ increase at a $2.5 \times$ frequency.

Milking capacity of an AMS can vary greatly with barn design and cow management. This effect was studied by increasing the capacity by $10 \%$. This was equivalent to allowing 1.6 more hours per day of operating time, which increased the capacity of a single-stall AMS by five to six cows per day. The effect of this change varied across farms. On farm sizes where the AMS was already oversized, this change had no effect unless it allowed the removal of a milking stall. On farms where capacity was limiting milking frequency, this increase allowed greater frequency and thus greater milk production.

The initial cost of this new technology may decrease with further development and greater sales. This effect was determined by reducing the initial equipment cost by 10 and $20 \%$. The economic life of this new technology is also uncertain. Assuming a life equal to that of the traditional system $(10 \mathrm{yr})$ may be optimistic. To determine this effect, depreciation of the AMS equipment was reduced to $7 \mathrm{yr}$, a life assumed in previous studies (Dijkhuizen et al., 1997; Rotz et al., 2001; Hyde and Engel, 2002). Repair and maintenance of the AMS represents a substantial annual cost to the producer, so the benefit of reducing this annual cost by $20 \%$ was determined. The effect of electrical requirement was evaluated by increasing the annual electrical use of the AMS by an additional $20 \%$ or $100 \mathrm{kwh} / \mathrm{cow}$.

Labor requirement and cost are important considerations for an AMS. Labor required for maintaining current AMS equipment is substantial. Improving the reliability and efficiency of this equipment may reduce this requirement in the future. This effect was determined by reducing the labor for milking and animal handling with an AMS by $20 \%$ (to $1.6 \mathrm{~min} /$ cow per day). Effect of labor cost was first determined by increasing the wage of milking labor by $20 \%$ to represent a slightly higher cost. Labor cost was then doubled to reflect a much higher value to this labor, which may be justified if the farm manager supplies most of the milking labor.

The final consideration was milk price. Milk price has been somewhat unstable, with a general decline in the real (inflation adjusted) price in recent years. This effect was determined by assuming a $10 \%$ decrease in mailbox price relative to all other price assumptions.

\section{RESULTS AND DISCUSSION}

Long-term differences in farm performance and economics due to milking system and frequency are quanti- fied in the simulation results. The important results to consider are the comparisons among simulated strategies, not the absolute values generated for a particular strategy or farm. These relative differences provide a meaningful evaluation of the effects of system changes.

\section{Milking Systems on a 120-Cow Farm}

Whole-farm effects of seven milking strategies were extensively evaluated on a 120-cow farm for herds at moderate and high milk production levels (Table 3). At the moderate production level, a moderate cost parlor was compared to two options with AMS. With a $2 \times$ milking frequency in the parlor, the herd maintained an annual production level of $8600 \mathrm{~kg} / \mathrm{cow}$. Average annual feed use, farm nutrient balance, production costs, and the net return for this production system are shown in column 1 of Table 3.

When the traditional parlor was replaced with an AMS using two single-stall milking units, the milking capacity was marginal for this farm size, providing an average milking frequency of $2.5 \times$. Milk production was the same as that of the traditional parlor, so feed use, farm nutrient balance, and most production costs were also similar (column 2 vs. column 1, Table 3). Annualized milking equipment costs more than doubled, along with a $17 \%$ reduction in the facility cost and a $46 \%$ reduction in the labor cost for milking and animal handling. Together, these cost changes provided an average annual net return that was $\$ 156 /$ cow less than that of the traditional parlor system. Compared with the net return for this farm using the higher cost traditional parlor ( $\$ 513 /$ cow, data not shown), the two-stall AMS provided $10 \%$ less return.

Adding another AMS unit provided sufficient capacity for a $3 \times$ milking frequency. To obtain the resulting $5 \%$ increase in milk production, forage use and the purchase of supplemental feeds increased (column 3, Table 3 ). This led to greater manure excretion, slightly greater nitrogen losses, and a small accumulation of excess soil phosphorus. The annual milking equipment cost increased by an additional $\$ 231 /$ cow along with some minor production cost increases due to greater feed use and manure production. Greater milk sales, along with a $2 \%$ lower milk price, increased farm income by $\$ 62 /$ cow. The net return of $\$ 258 /$ cow was less than that attained with either the parlor system or an AMS using two milking stalls. Thus, the increased production obtained through a greater milking frequency did not justify the added investment of another AMS unit.

At the high milk production level, two traditional parlor scenarios were compared to AMS. The first parlor system was the moderate cost double-eight parlor with a $2 \times$ milking frequency. Milk production level was in- 
Table 3. Effect of milking equipment and production level on annual feed production, feed use, nutrient balance, production costs, and the net return to management and unpaid factors for a 120 -cow dairy farm. ${ }^{1}$

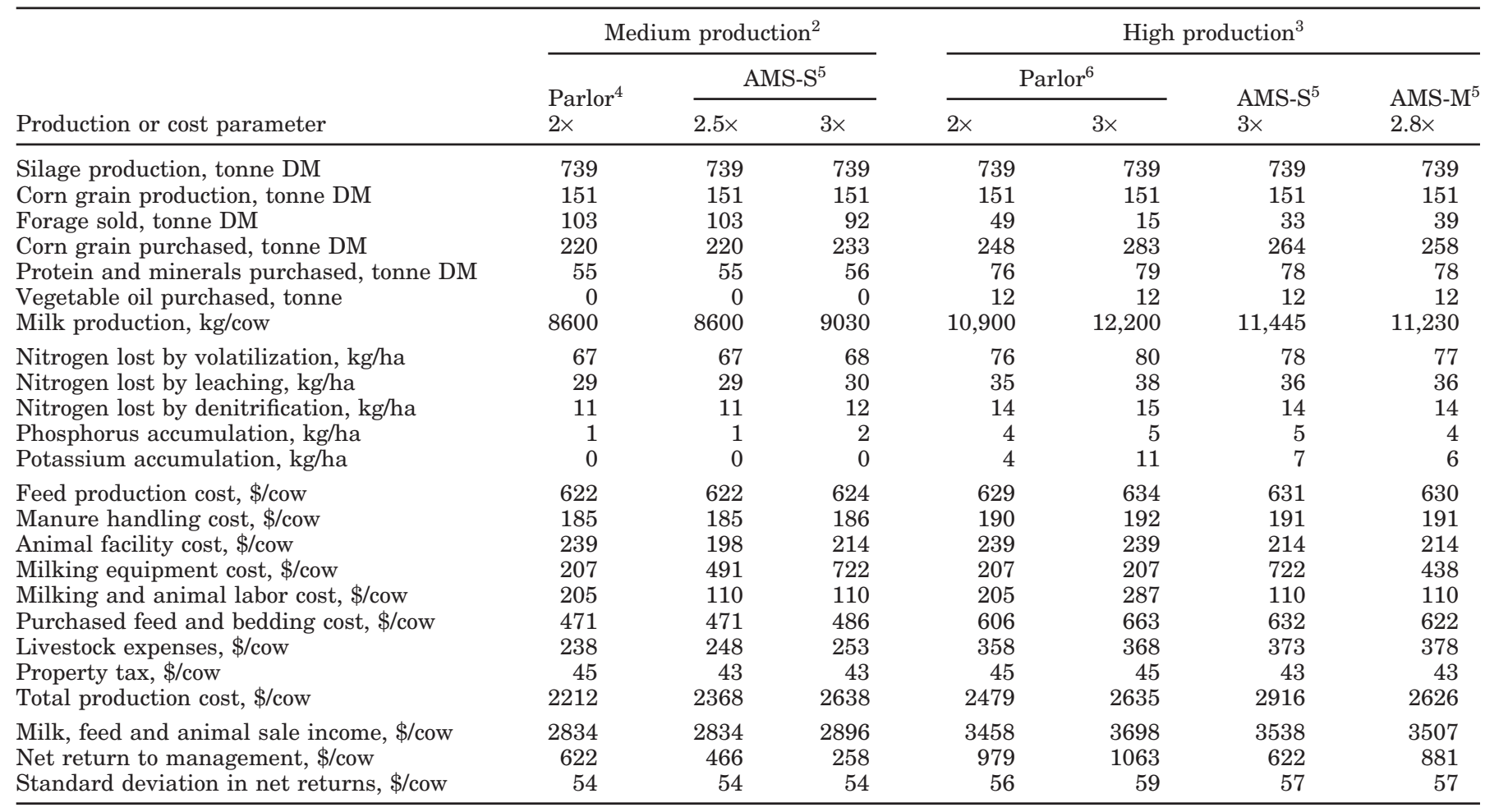

${ }^{1} 120$ mature cows and 91 replacement heifers on 97 ha in alfalfa and corn simulated over 25 yr of State College, Pennsylvania weather.

${ }^{2}$ Milk production of $8600 \mathrm{~kg}$ per cow with two times a day milking.

${ }^{3}$ Milk production of $10,900 \mathrm{~kg}$ per cow with two times a day milking.

${ }^{4}$ Moderate cost, double eight parlor with two times a day milking.

${ }^{5}$ Automatic milking using either two single-stall (AMS-S) units for 2.5 times a day milking, three single-stall units with three times a day milking, or a multiple stall (AMS-M) unit with 2.8 times a day milking.

${ }^{6}$ Moderate cost, double eight parlor with two or three times a day milking.

creased to $10,900 \mathrm{~kg} / \mathrm{cow}$ through feeding changes and other management improvements. Compared to the same system at a moderate production level, feed use, nitrogen loss, and excess phosphorus accumulation increased (column 4 vs. column 1, Table 3). Purchased feed costs and livestock expenses both increased, raising production costs by $\$ 267 /$ cow. Increased income more than offset these additional costs, increasing the annual net return by $\$ 357 /$ cow.

Next, the same parlor system was simulated with a $3 \times$ milking frequency. This further increased feed use, milk production, nutrient loads, and production costs (column 5 vs. column 4, Table 3). The increased milk sales offset increased production costs providing an $\$ 84 /$ cow increase in annual net return.

Use of an AMS to attain the $3 \times$ milking frequency was again not economically beneficial for this farm size (column 6 vs. column 5, Table 3). Because lower milk production was maintained compared with the $3 \times$ parlor system, feed use and production costs were also less. With three AMS units, annual milking equipment and facility costs were $\$ 490 /$ cow greater than the moderatecost parlor, and annual labor cost was $\$ 177 /$ cow less, leading to a $\$ 441 /$ cow lower net return (column 6 vs. column 5, Table 3 ). Using a multiple-stall system with one robot servicing three stalls reduced the annual milking equipment cost by $\$ 284 /$ cow. This system constrained milking frequency a small amount, which affected feed use and milk production. Annual net return was increased by $\$ 259 /$ cow compared with three singlestall units, but this return was still less than that attained with a moderate-cost traditional parlor (column 7, Table 3). Compared with an annual net return of $\$ 870 /$ cow with the high-cost parlor and $2 \times$ milking frequency (data not shown), the multiple-stall system provided a small economic benefit.

The preceding simulations illustrate for this particular farm and the current AMS equipment cost that this new technology can provide farm net returns approaching that of traditional parlors only when the capacity of the AMS is used at its maximum. Adding another milking stall to attain a greater milking fre- 


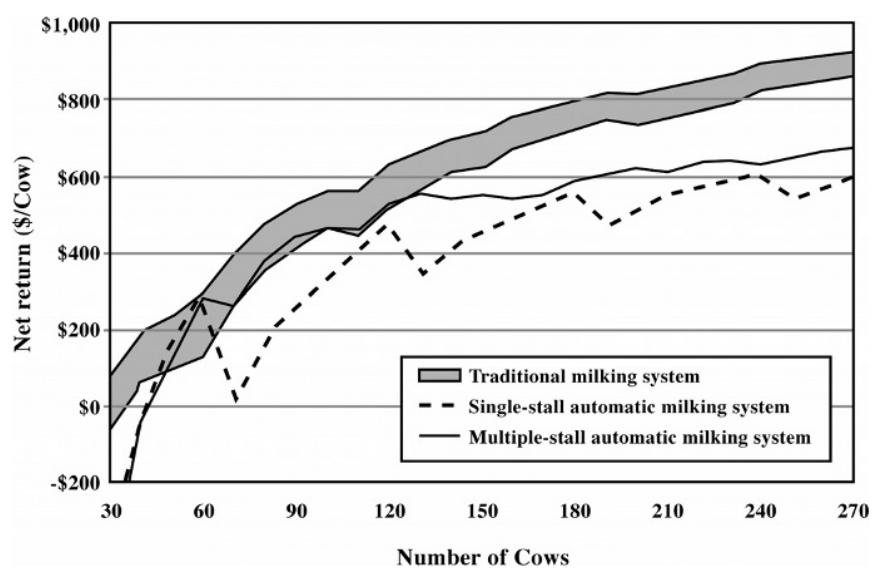

Figure 1. Annual net return to management and unpaid factors for farms with 30 to 270 cows at a moderate milk production level (8600 to $9000 \mathrm{~kg} / \mathrm{cow}$ per year) as influenced by milking system. Traditional systems represent a range in initial cost where higher cost technology includes recording of production information similar to that obtained from automatic milking systems.

quency and increased milk production caused a substantial loss in annual net return unless this stall shared a milking robot with another stall. If greater milk production is attained through a greater milking frequency with either a parlor or AMS, feed use must also increase. Increased feed use leads to greater manure production, which, depending upon animal density and other management characteristics, likely leads to small increases in nutrient loads on the farm and greater nutrient loss to the environment.

\section{Milking Systems over a Range in Farm Size}

The whole-farm net return varies considerably over the range in farm size of 30 to 270 cows. At a moderate production level along with the other assumptions in farm design, a moderate-cost traditional system with a $2 \times$ milking frequency provided an annual net return from $\$ 75 /$ cow, with 30 cows up to $\$ 925 /$ cow with 270 cows (Figure 1). With the higher cost parlor technology, the annual net return was reduced about $\$ 100 /$ cow across all farm sizes. The economic comparison of automatic to traditional milking systems also varied with farm size. The incremental increases in milking system capacity created an uneven relationship between net return and farm size. This was true for all milking systems, but particularly for the single-stall type AMS. When AMS capacity was well matched to herd size, net return was higher and more competitive with that of the traditional system on small farms.

For herd sizes of 30 to 40 cows, an AMS was not economical. The low net return on these herd sizes occurred because the high investment in milking equip- ment was underutilized. At 50- to 60-cow farm sizes, a single AMS unit was better utilized, providing an equal or greater return than traditional milking systems. At 50 cows, milking capacity was sufficient to allow $3 \times$ and greater milking frequencies. With a 60 -cow herd size, one AMS unit was operating near its maximum capacity providing a $2.5 \times$ milking frequency. Under our assumptions and at this herd size, a greater economic return was attained using a single unit with a $2.5 \times$ milking frequency than attained with the added investment of two units and a $3 \times$ frequency. In the range of 110 to 120 cows, two single-stall AMS units provided a net return similar (within $\$ 50 / \mathrm{cow}$ ) to that of a high cost parlor (Figure 1). The lower investment in a multiplestall AMS led to a higher net return that was competitive with traditional parlors on farm sizes of 50 to 130 cows.

For herds of more than 120 cows, traditional parlors were more labor efficient, and the initial investment per animal was less. Therefore, on these farms, the high investment and reduced labor saving of an AMS did not provide a net return that exceeded that of traditional parlors. Across farm sizes of 130 to 270 cows, the annual net return of single-stall AMS systems was $\$ 175$ to $\$ 275 /$ cow less than that using the higher cost traditional parlors (Figure 1). This economic difference was least at farm sizes around 180 and 240 cows, where animal numbers were well matched to the maximum capacity of the AMS. Multiple-stall systems provided more flexibility in matching a lower cost AMS with all herd sizes across this range. Thus, there was less variation in farm net return across farm sizes, and the net return was within $\$ 200 /$ cow of that attained with high cost parlor systems (Figure 1).

At the high milk production level, the net return per cow was considerably greater for all farm sizes and milking systems. This $26 \%$ increase in production increased net return by about $\$ 350 /$ cow across all farm sizes (Figure 2 vs. 1). An economic comparison of milking systems at this production level showed AMS to be slightly less economical. Only at the 50-cow farm size were the net returns similar between single-stall AMS and traditional systems. In the range of 90 to 110 cows, the capacity of two AMS units was well utilized, providing a net return within $\$ 100 /$ cow of that attained with high cost parlors. A multiple-stall AMS was again able to remain economically competitive with higher cost parlors over the range of 50- to 130-cow farm sizes (Figure 2).

With herd sizes of 120 cows or more, the net return using single-stall AMS was $\$ 200$ to $\$ 325 /$ cow less than that of traditional parlor systems (Figure 2). Multiplestall systems provided a greater net return, but this return remained below that of traditional parlors. The 


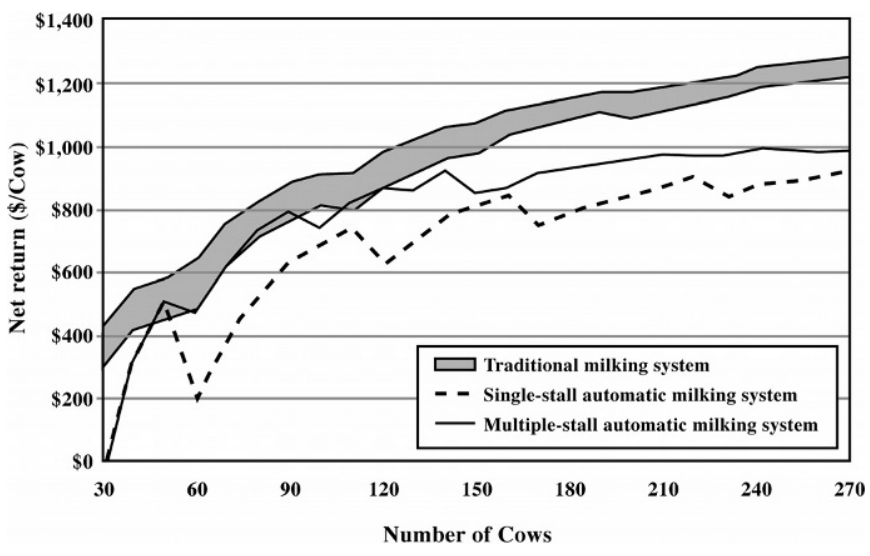

Figure 2. Annual net return to management and unpaid factors for farms with 30 to 270 cows at a high milk production level (10,900 to $11,400 \mathrm{~kg} / \mathrm{cow}$ per year) as influenced by milking system. Traditional systems represent a range in initial cost where higher cost technology includes recording of production information similar to that obtained from automatic milking systems.

greater difference in net return between milking systems implies that an AMS is slightly less economically competitive at higher production levels. On these farm sizes, the increased milking time to obtain the extra milk reduced the capacity of the AMS units. Thus, the milking frequency decreased or another milking stall was added to meet the required capacity. Because the capacity of traditional parlors was not influenced as much by the milking time of individual animals, the net return of parlors was not affected in this way.

\section{Sensitivity Analysis}

Increased milk production through more frequent milking with AMS is not always found on farms. If this increase cannot be maintained, the net return with automatic milking at a moderate production level is reduced by about $\$ 50 /$ cow on most farm sizes (Figure 3 ). However, on farms where the capacity of the AMS restricted milking frequency to less than $3 \times$, this effect would be less, with no effect on farms simulated with a $2.5 \times$ frequency $(60-, 120-, 180-$, and 240 -cow farm sizes). Thus, the most economical farm sizes for AMS in the primary analysis would not be affected.

Greater production increases than that used in the primary analysis have also been reported. If up to a $10 \%$ increase in milk production (an additional $5 \%$ across all farm sizes) is maintained, the benefit is an additional increase in annual net return of about $\$ 100 /$ cow (Figure 3 ). With all other assumptions held the same, this increase would allow the farm profitability with the single-stall type AMS to be equal or greater than that of traditional systems for farm sizes of 50 to 60 and 110 to 120 cows (Figure 1 ).

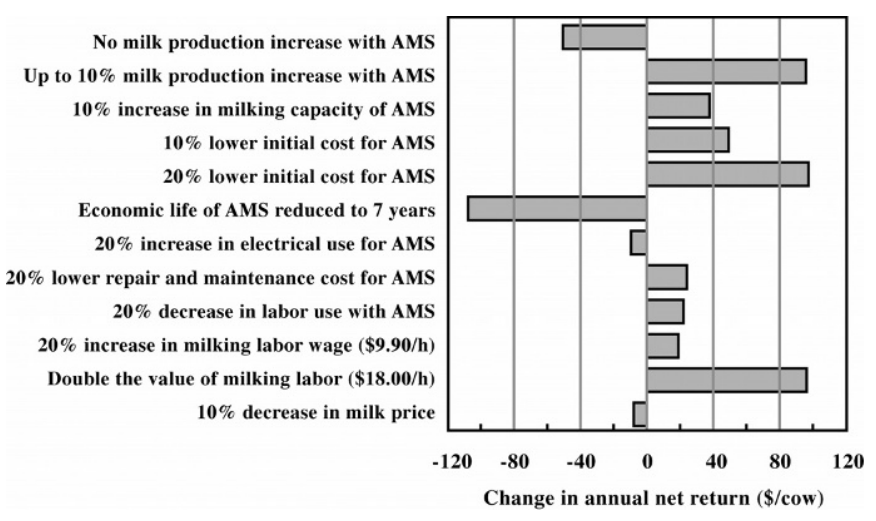

Figure 3. Effect of parameter changes on the annual net return of automatic milking systems (AMS) relative to traditional milking systems.

Milking capacity of the AMS can have a major effect on some farm sizes. On farms such as the 120-cow farm, where capacity limits milking frequency, an increase allows a greater milking frequency and increased production. This increases annual net return by about $\$ 40 /$ cow. On some other farms, an increase in capacity allows the herd to be milked with one less stall, but a lower production level is maintained. This increases the net return by up to $\$ 200 /$ cow. On farms with excess capacity such as those with 80 to 110 cows, an increase in capacity has no effect on net return.

As this technology is developed further and as the market expands, the initial cost may decrease relative to traditional parlors. Reductions in the initial cost of the AMS equipment of 10 and $20 \%$ increased the annual net return of these systems by $\$ 48$ and $\$ 97 /$ cow, respectively (Figure 3). Thus, relatively small reductions in the initial cost can greatly improve the economic return for using automatic milking, perhaps making it more competitive with traditional parlors on many farm sizes. Decreasing the economic life of the AMS though, greatly reduces its potential benefit. A 3-yr decrease in the depreciated life decreased the annual net return by almost $\$ 110 /$ cow (Figure 3).

Electrical use and the repair and maintenance cost of AMS had relatively small economic impacts. A $20 \%$ increase in electricity use reduced the annual net return with AMS by $\$ 10 / \mathrm{cow}$, and a $20 \%$ reduction in the repair and maintenance cost increased net return by $\$ 24 /$ cow (Figure 3).

The requirement and value of labor can also influence the economic comparisons of milking systems. Reducing the labor requirement for the AMS by $20 \%$ increased annual net return by $\$ 22 /$ cow. Relatively small changes in the price of labor such as a $20 \%$ increase in the wages paid had a relatively small effect on the economic 
difference between milking systems (Figure 3). Considering that the farm owner or manager provides much of the milking labor on many small farms, a much higher value may be assigned to this labor. Doubling the value of milking labor $(\$ 18 / \mathrm{h})$ reduced the economic difference between milking systems by $\$ 96 /$ cow. Thus, placing a much higher value on labor can make an AMS more easily justified.

Milk price had little effect on the long-term difference in net return among milking systems (Figure 3). A low price greatly reduced the potential net return, but because of relatively small differences in milk production, all milking systems were affected about the same amount.

\section{Additional Considerations}

Adoption of automatic milking may be difficult to justify for most situations on a purely economic basis. With efficient parlors and current prices for milking labor, cows can often be milked at a lower cost and better net return with traditional milking systems, particularly on larger farms. Other noneconomic issues will have more influence on the decision to adopt automatic milking. These issues include a desire for relief from the milking routine and an interest in electronic technology (Meskens et al., 2001; de Koning et al., 2002). Adoption of an AMS will always require a shift in the way labor is used. Routine chore labor will be replaced with labor for equipment and animal management. This shift will be welcomed by some farm managers and rejected by others.

Automatic milking may also offer benefits in the health and well being of the animals, but this potential benefit is difficult to ascertain. There is not a consensus on health benefits, and arguments can be made in favor of or in opposition to automatic milking (Meskens et al., 2001; Baines, 2002). With automatic milking, cows set their own milking schedule, which should better fit a natural pattern of more frequent milking. In a wellmanaged AMS, farmers note less stress among cows and fewer hierarchical battles within the herd. More frequent milking will allow less stress on the udder, particularly in early lactation. This reduces udder pressure and stress on udder ligaments and provides more comfort for the animal, especially when lying. More frequent milking may also reduce the time for the growth of mastitis organisms. However, more frequent and longer milking time may also cause more stress on teats. This can lead to an increased number of teat end erosions and eruptions. Because one set of teat cups serves a greater number of animals on a daily basis, bacteria may be spread faster from a cow with mastitis or a high SCC.
Healthier animals normally respond better to an AMS. Good legs and feet will encourage greater mobility and more frequent visits to the milking and feeding areas. Regular-shaped udders will also improve milking efficiency. Some animals will not adapt well to an AMS, which will increase the culling rate or at least the type of animals culled (Meskens et al., 2001; de Koning et al., 2002). If the AMS capacity is undersized (too many cows per milking unit), younger and weaker cows will suffer by missing milkings and perhaps visits to the feeding area.

This analysis was designed for a long-term assessment of automatic milking across farm sizes of 30 to 270 cows with management typical of that found in the northern United States. The prices assumed should reflect conditions after a number of milking systems are established, i.e., current conditions in Europe. Costs for early adoption in the United States may be higher than those assumed until the infrastructure is in place to support the sale and maintenance of the equipment. This analysis also assumes that the AMS is reliable enough that a substantial investment in a backup milking system is not required.

The integrated farm system model can be used to evaluate a wide range in technologies and management strategies for dairy farms. With this tool, the simulated long-term benefits of an AMS can be quickly compared to other potential farm changes. For those interested in further analysis and comparison of farm production systems, a Windows version of the integrated farm system model is available from the Internet home page of the Pasture Systems and Watershed Management Research Unit (http://pswmru.arsup.psu.edu). The program operates on computers that use any Microsoft Windows operating system. To obtain a copy of the program, including an integrated help system and reference manual (Rotz and Coiner, 2002), the home page can be accessed at the address given, where instructions for downloading and setting up the program are provided.

\section{CONCLUSIONS}

Automatic milking systems do not offer an economic benefit for most farm scenarios at this time. They can be competitive, however, when compared with the investment in a new traditional milking system on smaller farms (50 to 120 cows), where herd size is appropriately matched to the capacity of the milking system. On farm sizes above 60 cows, a multiple-stall AMS (one robot shared across two to four milking stalls), shows greater potential net return than the use of two or more single-stall units (one robot per stall). Herd milk production level has a small effect on the economic differ- 
ence between traditional and automatic milking systems with a greater difference at a higher production. The potential benefit of AMS is improved if a substantial increase in production (5 to 10\%) is maintained through a greater milking frequency with automatic milking. A reduction in the initial cost of AMS equipment or a large increase in the value of milking labor can improve the net return of an automatic system relative to traditional milking systems over all farm sizes. Farm net return with an AMS is greatly reduced if the economic life of the AMS is reduced to represent a more rapid depreciation than normally occurs with traditional milking systems. This analysis compares the installation and long-term use of new traditional and automatic milking systems. Replacement of an appropriately sized and functioning traditional system with automatic milking will have substantially less potential for economic benefit.

\section{ACKNOWLEDGMENTS}

The authors appreciate the guidance received in setting the parameters of this analysis from Jack Rodenburg, Dairy Production Systems Program, OMAFRA, Woodstock, Ontario, Canada; Morten D. Rasmussen, Department of Animal Health and Welfare, Danish Institute of Agricultural Sciences, Denmark; Jeffery A. Hyde, Department of Agricultural Economics and Rural Sociology, The Pennsylvania State University; and Robert E. Graves, Department of Agricultural and Biological Engineering, The Pennsylvania State University, University Park.

\section{REFERENCES}

Armstrong, D. V. 1997. Milking frequency. Pages 79-84 in Proc. Western Dairy Management Conference, Las Vegas, NV.

Artmann, R., and E. Bohlsen. 2001. Results from the implementation of automatic milking system (AMS)—multi-box facilities. Pages 221-231 in Robotic Milking. H. Hogeveen and A. Meijering, eds. Wageningen Pers, Wageningen, The Netherlands.

Baines, J. 2002. Managing the change to a robotic milking system. Pages III-9-III-17 in The First North American Conference on Robotic Milking, Wageningen Pers, Wageningen, The Netherlands.

Brooks, L. A. 1989. Electiric energy management on dairy farms. Pages 93-120 in Energy in World Agriculture. K. L. McFate, ed. Elsevier, Amsterdam, The Netherlands.

Campos, M. S., C. J. Wilcox, H. H. Head, D. W. Webb, and J. Hayen. 1994. Effects on production of milking three times daily on first lactation Holsteins and Jerseys in Florida. J. Dairy Sci. 77:770773.

Dijkhuizen, A. A., R. B. M. Huirne, S. B. Harsh, and R. W. Gardner. 1997. Economics of robotic application. Computers Electronics Agric. 17:111-121.

Hyde, J., and P. Engel. 2002. Investing in a robotic milking system: A Monte Carlo simulation analysis. J. Dairy Sci. 85:2207-2214.

Ipema, A. H. 1997. Integration of robotic milking in dairy housing systems. Review of cow traffic and milking capacity aspects. Computers Electronics Agric. 17:79-94.
Klungel, G. H., B. A. Slaghuis, and H. Hogeveen, 2000. The effect of the introduction of automatic milking systems on milk quality. J. Dairy Sci. 83:1998-2003.

Knoblauch, W. A., and D. M. Galton. 1992. Economic considerations in milking center design. Pages 21-28 in Milking Center Design. NRAES-66, Northeast Regional Agricultural Engineering Service, Ithaca, NY.

de Koning, K., and W. Ouweltjes. 2001. Maximizing the milking capacity of an automatic milking system. Pages 38-46 in Robotic Milking. H. Hogeveen and A. Meijering, eds. Wageningen Pers, Wageningen, The Netherlands.

de Koning, K., Y. van der Vorst, and A. Meijering. 2002. Automatic milking experience and development in Europe. Pages I-1-I-11 in The First North American Conference on Robotic Milking, Wageningen Pers, Wageningen, The Netherlands.

McFate, K. L. 1989. Electricity used in farmstead operations. Pages 121-142 in Energy in World Agriculture. K. L. McFate, ed. Elsevier, Amsterdam, The Netherlands.

Mein, G., and D. A. Reid. 1996. Milking-time tests and guidelines for milking units. Pages 235-244 in Proc. 35th Annual Meeting National Mastitis Council, Madison, WI.

Meskens, L., M. Vandermersch, and E. Mathijs. 2001. Literature review on the determinants and implications of technology adoption. Deliverable no. 1 of EU project 'Implications of the introduction of automatic milking on dairy farms', work package 1, Socio-economic aspects of automatic milking. http://www.automaticmilking.nl/ Projectresults/Reports/Deliverable D1.pdf.

Reinemann, D. J., and D. J. Smith. 2001. Evaluation of automatic milking systems for the United States. Pages 232-238 in Robotic Milking. H. Hogevee and A. Meijering, eds. Wageningen Pers, Wageningen, The Netherlands.

Rotz, C. A., and C. U. Coiner. 2002. Integrated Farm System Model: Reference Manual. USDA Agricultural Research Service, University Park, PA. Available at: http://pswmru.arsup.psu.edu.

Rotz, C. A., C. U. Coiner, and K. J. Soder. 2001. Economics of robotic milking on a dairy farm in the United States. Pages 115-122 in Farm Work Science Facing the Challenges of the XXI Century. T. Juliszewski, ed. Wageningen Pers, Wageningen, The Netherlands.

Rotz, C. A., D. R. Mertens, D. R. Buckmaster, M. S. Allen, and J. H. Harrison. 1999a. A dairy herd model for use in whole farm simulations. J. Dairy Sci. 82:2826-2840.

Rotz, C. A., L. D. Satter, D. R. Mertens, and R. E. Muck. 1999b. Feeding strategy, nitrogen cycling, and profitability of dairy farms. J. Dairy Sci. 82:2841-2855.

Rasmussen, J. B., and M. D. Rasmussen. 2002. The power consumption rises with AMS, the water consumption remains the same. Pages VI-63-VI-65 in The First North American Conference on Robotic Milking, Wageningen Pers, Wageningen, The Netherlands.

Rasmussen, M. D., M. Bjerring, P. Justesen, and L. Jepsen. 2002. Milk quality on Danish farms with automatic milking systems. J. Dairy Sci. 85:2869-2878.

Shimmin, S. W., and E. D. Stout. 2002. Pennsylvania machinery custom rates 2002. Pennsylvania Agricultural Statistics Service, Harrisburg.

Shoshani, E., and M. Chaffer. 2002. Robotic milking: A report of a field trial in Israel. Pages III-56-III-63 in The First North American Conference on Robotic Milking, Wageningen Pers, Wageningen, The Netherlands.

Sonck, B. R., and W. J. Donkers. 1995. The milking capacity of a milking robot. J. Agric. Eng Res. 62:25-38.

Speicher, J. A., H. A. Tucker, R. W. Ashley, E. P. Stanisiewski, J. F. Boucher, and C. J. Sniffen. 1994. Production responses of cows to recombinantly derived bovine somatotropin and to frequency of milking. J. Dairy Sci. 77:2509-2517.

Wangler, A., P. Sanftleben, and O. Weiher. 2002. Milk yield and constituents under conditions of milking systems. Pages V-76-V-79 in The First North American Conference on Robotic Milking, Wageningen Pers, Wageningen, The Netherlands.

Wirtz, N., K. Oechtering, E. Tholen, and W. Trappmann. 2002. Comparison of an automatic milking system to a conventional milking parlour. Pages III-50-III-55 in The First North American Conference on Robotic Milking, Wageningen Pers, Wageningen, The Netherlands. 